ISSN: 1110-5623 (Print) - 2090-0570 (Online)

\title{
THE EFFECT OF ADDITION OF CHAMOMILE FLOWER TO SUDANI DUCKLING DIETS DURING GROWING PERIOD ON GROWTH PERFORMANCE, BLOOD PARAMETERS AND ECONOMIC EFFICIENCY
}

\section{$\operatorname{Gad}^{1}$ H. A., A. M. EL-Shhat ${ }^{1}$ and Basma M Hamed ${ }^{2}$}

${ }^{1}$ Anim. Prod. Res. Inst., Agric. Res. Center, Minis. of Agric. Dokki, Giza, Egypt.

${ }^{2}$ Dep. Anim. Phys., Fac.Vet. Med. Mansoura Univ., Egypt.

Corresponding author: abdelghany587@gmail.com \begin{abstract}
Received: $28 / 08 / 2018$ Accepted: 12/09/2018

ABSTRACT:A total number of 225 Sudani ducklings at one-day-old were used, weighed and divided into three experimental groups (each of three replicates) to investigate the effect of dried chamomile flower (DCF) addition at different levels (0.0, 1.0 and $3.0 \mathrm{~g} / \mathrm{kg}$ ) on growth performance, carcass traits, blood parameters and economic efficiency. The results indicated that dietary DCF with $1.0 \mathrm{~g} / \mathrm{kg}$ resulted in a significant $(\mathrm{P} \leq 0.01)$ increased in live body weight at 16 weeks of age, while body weight gain, and performance index were significantly $(\mathrm{P} \leq 0.05)$ improved as compared to the control group during the overall experimental period $(0-16$ weeks of age). In spite of, eviscerated carcass and total edible parts $(\%)$ were not significantly affected by different levels of dietary DCF addition, but abdominal fat (mg/100 $\mathrm{g} \mathrm{LBW}$ ) was high significantly $(\mathrm{P} \leq 0.01)$ decreased. Relative weights of gizzard and total giblets were significantly $(\mathrm{P} \leq 0.05)$ higher in ducklings fed diet supplemented with $1.0 \mathrm{~g}$ DCF. Plasma total lipids, cholesterol, triglycerides and low-density lipoproteins (LDL) cholesterol were significantly decreased by supplementing DCF with 1.0 and $3.0 \mathrm{~g} / \mathrm{kg}$ diet. Plasma liver function parameters were significantly increased as a result of diet addition with DCF except globulin which was significantly decreased. Hemoglobin $(\mathrm{Hb})$ and red blood cells (RBCs) were insignificantly affected by DCF treatments, however, treatments caused significantly increased in white blood cells (WBCs). Economic efficiency was improved for ducklings fed diets supplemented DCF with 1.0 $\mathrm{g} / \mathrm{kg}$ diet. The obtained data suggest that dietary DCF $1.0 \mathrm{~g} / \mathrm{kg}$ for Sudani ducklings during growing period may be could improve growth performance and economic efficiency besides, reduce abdominal fat, total lipids, cholesterol, triglycerides and LDL cholesterol.
\end{abstract}

Key words:Chamomile flower-growth performance-abdominal fat-cholesterol and ducklings. 
$\operatorname{Gad}^{1}$ H. A.,et al.

\section{INTRODUCTION}

Ducks are considered the second common strains of poultry in the world. In Egypt, more attention is focused lately on increasing ducks meat production (ElSoukkary et al., 2005; Awad et al., 2009 and Kout Elkloub et al., 2010). Egyptian duck production was 42.0 thousand tons representing about $1.7 \%$ from the world production in 2006 (Soltan et al., 2014). It is becoming specialized and attention focused lately to increase meat production especially from local breeds. Sudani is considered a local duck breed in Egypt and it is more heat tolerant as compared to the other breed ducks therefore it is known a predominate of dining table in the banquets hence, it is more favorable to the Egyptian consumer because it was high nutritional value and its delicious taste. More consumers prefer low cholesterol foods and pay attention to the relationship between dietary cholesterol and coronary diseases (Muhamad et al., 2014).On the other hand, feed cost is an important and critical input for the poultry industry as it accounts for $60-70 \%$ of total production costs (Singh et al 2015). Some medicinal and aromatic plants seem to have improving growth performance and marketing weights in order to reduce the feed cost to increase the economic return.Chamomile flower (Matricaria chamomilla L.) is one of aromatic and medicinal plants are preferable as feed additives and growth promoters in poultry diets. It shows different pharmacological activities such as antioxidant, antimicrobial and cholesterol-lowering activities (McKay and Blumberg, 2009). One of chamomile's main roles is as a multipurpose digestive aid to treat gastrointestinal disturbances including indigestion and diarrhea (Panda, 2005 and
McCrea et al., 2005).Ibrahim et al., (2014) found that supplementing growing Pekin ducks diet with chamomile by $0.75 \%$ level significantly $\quad(\mathrm{P} \leq 0.05)$ increased the final body weight and average daily body weight gain as well as it is improves carcass quality and growth performance of Pekin ducks by reducing fat deposition. Abaza et al., (2003) suggested that addition of $2.5 \mathrm{~g}$ chamomile flower $/ \mathrm{kg}$ broiler diet improved growth performance. Mahmmod (2013) reported that supplementing chamomile flower to broiler diet with 0.5 up to $1.5 \mathrm{~g} / \mathrm{kg}$ improved growth performance during growth period.Very few researches have been conducted evaluating the additives effects of chamomile flower on ducks. Therefore, the current study aimed to evaluate the effect of dietary chamomile flower heads addition on growth performance, carcass traits, blood parameters and economic efficiency of Sudani ducklings during the growing period.

\section{MATERIALS AND METHODS}

This study was conducted at El-Serw Waterfowls Research Station, Damietta, Animal Production Research Institute, Agricultural Research Center, Egypt.

Birds, experimental, management and diets:

A total number of two hundred and twenty five unsexed Sudani ducklings one-day old were used, weighted (g) and divided into three experimental groups, each of equal three replicates to investigate the effect of dietary chamomile (Matricaria chamomilla L.) flower addition by levels of 0.0, 1.0 and $3.0 \mathrm{~g} / \mathrm{kg}$. The $1^{\text {st }}$ experimental group was fed on the basal diet without any addition and used as a control, while the $2^{\text {nd }}$ and $3^{\text {rd }}$ experimental groups were fed on the 
Chamomile flower-growth performance-abdominal fat-cholesterol and ducklings.

same basal diet supplemented with 1.0 and $3.0 \mathrm{~g}$ chamomile flower $/ \mathrm{kg}$ diet, respectively. All ducklings were reared under similar hygienic and managerial conditions .They were housed in well ventilated brooding pens from one-day up to 3 weeks of age. At the end of brooding period ducklings were permitted to go out yards. Ducklings of each replicate were housed as 4.5 ducklings $/ \mathrm{m}^{2}$ in a house with windows. Wheat chaff was used as a litter throughout the experimental period. Fresh water and mash feed were offered ad-labium. The experimental period lasted for 16 weeks. A starter diet was used during the starter period (one-day up to 4 weeks of age), while the grower diet was used during the rearing period (4-16 weeks of age). The diets were formulated from plant origin according to Feed Composition Tables for Animals and Poultry Feedstuffs used in Egypt (2001). The composition and calculated analysis of these diets are presented in Table 1.

\section{Data collection and estimated parameters: \\ Growth parameters:}

Live body weight (LBW, g) and feed consumption were recorded every week for each replicate of all experimental groups, then averaged per duckling every four weeks intervals $(0-4,4-8,8-12,12$ 16 weeks of age) and 0-16 weeks of age as the whole experimental period. Body weight gain and feed conversion ratio ( $\mathrm{g}$ feed/g gain) were calculated during the same intervals. Also, performance index of the ducklings was calculated as the following equation (live body weight, $\mathrm{Kg}$ / feed conversion ratio $\times 100$ ) according to North (1984). Mortality number was recorded, and then duckling's viability (\%) was calculated through the whole experimental period.

\section{Carcass traits:}

At the end of the 16 weeks of age, a total number of 18 ducklings ( 3 drakes and 3 females from each treatment) were taken randomly and fasted for 12 hrs before. Ducklings were weighed just before slaughter and after complete bleedingremoval of the feathers by hand, carcasses were manually eviscerated to determine some carcass traits, as weights of eviscerate carcass, liver, heart, gizzard, total-giblets, and edible weight as well as determination of dressing percentage. Weight of abdominal fat was recorded and expressed as relative weight (mg /100 $\mathrm{g}$ of live body weight) according to Haddad (1989).

\section{Plasma biochemical and Hematological parameters:}

Blood samples were collected at slaughtering in a separate two a liquate in heparinized test tubes. The first heparinized tube was immediately used for hematological estimation (Hb , RBC's and WBC's) according to the procedure of Jain (1986). While another centrifuged at $3500 \mathrm{rpm}$ for 15 minutes to obtain plasma that stored frozen at $-20^{\circ} \mathrm{C}$ till analysis to determine total lipids, triglyceride, total cholesterol, highdensity lipoprotein (HDL), low-density lipoprotein (LDL), total protein and albumin. Globulin level values were obtained by subtracting the values of albumin from the corresponding values of total protein. The activities of aspartate aminotransferase (AST) and alanine aminotransferase (ALT) were estimated according to Tietz (1990).

\section{Economic evaluation:}

Feed economic efficiency was calculated according to input-output analysis (Heady and Jensen, 1954). 
$\operatorname{Gad}^{1}$ H. A.et al.

\section{Statistical analysis:}

Data were statistically analyzed according to ANOVA procedures of SAS (SAS institute, 2001), Means differences were compared using Duncan's Multiple Range Test (Duncan, 1955). The statistical model used was: $Y_{i j}=\mu+T_{i}+E_{i j}$ Where; $Y_{i j}$ is the experimental observation; $\mu$ is the overall mean; $T_{i}$ is the effect of the dietary treatments, and $\mathrm{E}_{\mathrm{ij}}$ is the random error.

\section{RESULTS AND DISCUSSION}

\section{Live body weight}

Results of Table 2 shows that the effect of dietary DCF addition on live body weight and body weight gain of Sudani ducklings during the growing period. Live body weight (LBW) was significantly $(\mathrm{P} \leq 0.01)$ increased by $12.13 \%$ as a result of DCF addition by $1.0 \mathrm{~g} / \mathrm{kg}$ diet as compared to the control group at the end of experimental period(16 weeks of age), while, the high level of DCF addition (3.0 $\mathrm{g} / \mathrm{kg}$ diet) had no significant effect. These improved parameters might be related to the active components of chamomile. McCrea et al. (2005) reported that active components of chamomile (flavonoids, kamasolen and bisaboldaxid essential oils) have the same role as probiotics and thus improve natural intestinal microflora and may be help in the absorption of nutrient which increase the growth. This is in support with results obtained by Abaza et al., (2003), Ibrahim and Butris (2008), Galib and Khalel et al., (2011) and Mahmmod (2013). Also, Ibrahim et al., 20014 added that DCF at $0.75 \%$ level significantly $(\mathrm{P}<0.05)$ increased the final body weight of Pekin ducks at 12 ago by $11.6 \%$ compared to the control group. In contrary, Dada and Tabeidian (2015) showed that feeding diets broiler chickens with supplemented chamomile extract or powder chamomile extract had no significant effect on growth performance parameters.

\section{Body weight gain}

The same trend was observed in body weight gain and the differences were significant $(\mathrm{P}<0.05)$ among the three groups (Table 2). The highest value of body weight gain $(2535.72 \mathrm{~g})$ was recorded by DCF addition with $1.0 \mathrm{~g} / \mathrm{kg}$ diet and the lowest value $(2257.51 \mathrm{~g}$.) was detected with the control group at the whole of the experimental period (1-d to 16 weeks of age). The improvement in body weight gain of ducklings may be due to the ability of chamomile flowers to improve the digestibility via reduces the upper gastrointestinal motility as the result may positively effect on ducklings health and productivity (Capasso, et al. (2007). These results are in agreement with those obtained by obtained by Abaza et al., (2003), Ibrahim and Butris (2008), Galib and Khalel et al., (2011) and Mahmmod (2013) who reported that dietary DCF addition had positive effects on body weight gain of broiler. Also, Ibrahim et al. (2014) reported that the addition of chamomile flower by $0.75 \%$ level to the diet significantly $(\mathrm{P} \leq 0.05)$ improved body weight gain of Pekin ducklings at 12 weeks of age as compared to the control group. In contrary, Dada and Tabeidian (2015) showed that feeding diets supplemented with chamomile extract or powder chamomile extract had no significant effect on growth performance parameters of broiler chickens.

No significant differences were observed among the experimental groups in Viability (\%) through the experimental period.

\section{Feed consumption}

The obtained data in Table 3 indicated that feed consumption values were not 
Chamomile flower-growth performance-abdominal fat-cholesterol and ducklings.

\begin{abstract}
significantly affected by dietary chamomile flower addition during all studied periods. However, ducklings fed diet supplemented with $1.0 \mathrm{~g}$ chamomile flower had recorded the highest amount of consumption (12735.33 g) than the control group (12673.00) during the whole of the experimental period (1-d to 16 weeks of age). Ibrahim and Butris (2008) reported that the addition of chamomile flower by 0.6 and $0.9 \%$ levels to the broiler diets high significantly $(\mathrm{P} \leq 0.01)$ increased the feed consumption values during the growing period.
\end{abstract}

\section{Feed conversion ratio}

Feed conversion ratio was not significant due to dietary chamomile flower addition during all experimental intervals except of the period from 4-8 weeks of age (Table 3). Generally, feed conversion ratio was improved by about $10.68 \%$ as a result of $1.0 \mathrm{~g}$ chamomile flower DCF addition as compared with the control group during the whole experimental period. Natural feed additives such as chamomile flower had beneficial effect for stimulation and activity of digestive system by improving the diet palatability and enhancing appetite of poultry (Galib and Khalel 2011). In addition, the improvement in feed utilization may be attributed to the properties of these materials that could act not only as antibacterial, anti-protozoa and antifungal but also as antioxidants (Leung and Foster, 1996). Ibrahim and Butris (2008) showed that the addition of chamomile flower by $0.6 \%$ level to the broiler diets significantly $(\mathrm{P} \leq 0.01)$ improved the feed conversion ratio during the growing period

\section{Performance index}

Performance index (\%) of Sudani ducklings was not significantly affected among all experimental treatments during the experimental intervals except of the periods of $4-8$ weeks of age and the overall period (1-d to 16 weeks) which was significantly $(\mathrm{P} \leq 0.05)$ affected (Table 3). Ducklings fed diet supplemented with $1.0 \mathrm{~g}$ chamomile flower had the best performance index $(\mathrm{P} \leq 0.05)$ as compared to the control group by about $25.07 \%$ at the whole experimental period(1-d to 16 weeks of age). Generally, these results were related to the live body weight and feed conversion ratio as reported earlier in (Tables 2 and 3). These improvements may be due to the synergetic effect of chamomile flower which works as antioxidant and antimicrobial activity.

\section{Carcass traits:}

Results of Table 4 shows the effect of dietary chamomile flower addition on carcass traits of Sudani ducklings at 16 weeks of age. No significant differences were observed among the experimental groups in relative total edible parts, eviscerated carcass and liver weight however, total giblet, gizzard and heart weights $(\%)$ were significantly affected as a result of chamomile flower addition to the diets. These results are in the same line with Abaza et al., (2003) and Ibrahim et al., (2014) who found that addition chamomile flower to diets was increased the gizzard and total giblet weight. While, Dada and Tabeidian (2015) showed that feeding diets supplemented with chamomile extract or powder had no significant effect on carcass traits of broiler chickens.

Duckling abdominal fat (mg/100 g LBW) was high significantly $(\mathrm{P} \leq 0.01)$ decreased with about 58.63 and $68.79 \%$ as a result of DCFaddition by 1.0 and $3.0 \mathrm{~g} / \mathrm{kg}$ levels in diet, respectively as compared to the control group as shown in Table 4. It could be observed that the decreasing is 
$\operatorname{Gad}^{1}$ H. A.et al.

positively related to the levels of DCF in the diet. This reduction of abdominal fat of Sudani ducklings was positively related to the decrease of plasma total lipids, triglycerides, total cholesterol, LDL cholesterol and VLDL cholesterol concentration (Table 5). These results may be attributed to the ability of chamomile components effective in reducing the lipid accumulation, or it may be attributed to a reduction of hepatic lipogenic enzyme activity which induces some morphological changes with the accumulation of vesicles electro dense lipid inclusions (Mckay and Blumberg, 2009). These results are in the same line with Ibrahim et al. (2014) who found that supplementing chamomile flower to Pekin ducks diet was decreased carcass abdominal fat as compared to the control group.

\section{Blood plasma constituents}

Lipid profile, liver function and blood hematological parameters of Sudani ducklings fed diet supplemented with chamomile flower during rearing period are shown in Table 5. Total lipids were significantly $(\mathrm{P} \leq 0.05)$ decreased as a result of supplementing chamomile flower with 1.0 and $3.0 \mathrm{~g} / \mathrm{kg}$ diet by 20.35 and $21.87 \%$, respectively as compared to the control group. The reduction of plasma triglycerides were affected significantly $(\mathrm{P} \leq 0.05)$ by about $29.54 \%$ and $36.20 \%$ than the control group as a result of chamomile flower addition to the diets with 1.0 and $3.0 \mathrm{~g} / \mathrm{kg}$ diet, respectively. Plasma total cholesterol was significantly $(\mathrm{P} \leq 0.01) \quad$ decreased by $17.43 \%$ and $29.58 \%$ as a result of supplementing DCF by 1.0 and $3.0 \mathrm{~g} / \mathrm{kg}$ diet, respectively as compared to the control group. Moreover, addition of chamomile flower at the levels 1.0 and $3.0 \mathrm{~g} / \mathrm{kg}$ diet succeeded to reduce the concentration of plasma LDL cholesterol significantly $(\mathrm{P} \leq 0.01)$ than the control group by 23.13 and $40.78 \%$, respectively. In the same track, plasma VLDL cholesterol was high significantly $(\mathrm{P} \leq$ 0.01 ) decreased by 19.52 and $41.40 \%$ when the chamomile flower supplemented by 1.0 and $3.0 \mathrm{~g} / \mathrm{kg}$ diet, respectively as compared to the control group. Moreover, addition of this material succeeded to reduce the concentration of plasma total lipids, triglycerides, total cholesterol, LDL cholesterol and VLDL cholesterol were positively related to the increasing of levels of chamomile flower heads. It is may be attributed to the biological function of chamomile components such as phytoesterol and flavonoids like cyranosid and patulitrin which posse antimicrobial and pharmacological activities (Gosztola, 2006 and Saberi et al., 2014). Results of this experiment showed that DCF could be used as an effective medicinal plant to decrease the levels of lipid profile in Sudani ducklings plasma. Chamiloflan, the effective component in (Matricaria chamomilla L.) flowers might be attributed to increase cholesterol bile secretion and reduced lipid content in the liver (Babenko and Shakhova 2005). This result is agreement with the finding of Galib and Khalel (2011) who reported that the addition of chamomile flowers powder to broiler diets decreased serum total cholesterol as compared to the control group. Also, these findings are in the same line with the findings of Radwan (2003).

The results of liver function in Table 5 indicated that plasma globulin was significantly $(\mathrm{P} \leq 0.01)$ decreased while; plasma albumin and albumin/globulin ratio were significantly increased as a result of supplementing different levels of 
Chamomile flower-growth performance-abdominal fat-cholesterol and ducklings.

DCF to duckling diets than the control. In the same time, both liver enzymes activity (AST and ALT) were significantly $(\mathrm{P} \leq 0.05)$ higher by feeding diet supplemented with $3.0 \mathrm{~g}$ chamomile than those fed the control diet and $1.0 \mathrm{~g}$ chamomile flower. It clear observed that the DCF at $1.0 \mathrm{~g}$ level was insignificant effect as compared to control group. Chamomile is one of the medicinal herbs are used for their possible antioxidant and hepatoprotective effects against various chemical induced liver damages in animals (Merlin and Parthasarathy 2011). Their antioxidant activity may has clinical effects along with other components, mostly phenolic compounds and flavonoids. Ramadan and Emam (2012) who showed that chamomile had different pharmacological activities such as antioxidant, anti- cancer. Ibrahim et al. (2014) reported that the addition of chamomile to Pekin duck diets resulted in improving the globulin and albumin/ globulin ratio $(\mathrm{A} / \mathrm{G})$ as well as a significant decrease the liver enzymes activity (ALT and AST).

Data of Table 5 shows the effect of adding different levels of DCF on some hematological parameters. The values of WBCs count of Sudani ducklings were significantly increased by 36.36 and $45.45 \%$ as a result of adding DCF in 1.0 and $3.0 \mathrm{~g} / \mathrm{kg}$ levels, respectively as compared to the control group. While, concentration of hemoglobin and red blood cells count was little increased without significant effect by supplementing different chamomile flower levels than the control. The increase in $\mathrm{Hb}$ and RBC's parameters may be due to the activity of chamomile which may act like estrogen hormone (Sturkie 1979). These findings are in agreement with those reported by Abaza et al., (2003) and Abd El-Latif et al., (2003). In contaray, Galib and Khalel (2011) showed that dietary addition of chamomile flowers powder decreased the $\mathrm{RBCs}$ and $\mathrm{Hb}$ count without significant effect on WBCs count.

\section{Economics evaluation:}

Table 6, shows that Sudani ducklings fed diet supplemented with $1.0 \mathrm{~g}$ DCF during growing period results in the highest net revenue value $(11.93 \mathrm{LE})$ than the control group (4.22 LE) and this may be related to the improvement of body weight gain, feed conversion ratio and performance index (Tables 2 and 3). These results indicated that the diets containing DCF with level $1.0 \mathrm{~g} / \mathrm{kg}$ were more economic efficiency than the other experimental diets. In the same line with Abaza et al. (2003) who found that the economic efficiency was noticeable improved as a result to using of herbal medicinal plants such as DCF in the diets and this improvement could be due to improving the feed conversion ratio. Many attempts have been undertaken to improve the growth, feed conversion ratio and reduce the cost of feeds by addition of dietary herbal (Radwan, 2003). These results are agreement with those obtained by Ibrahim et al., (2014) who observed that the value of economic efficiency was improved with additive the chamomile flower in Pekin ducks diets.

\section{CONCLUSION}

It could be concluded that using of chamomile flower especially at level $1.0 \mathrm{~g} /$ $\mathrm{kg}$ die during growing period of Sudani ducklings had a positive effect live body weight, body weight gain, some metabolic parameters and performance, without adverse effect on blood profile or general health. This improvement was reflected on feed utilization, abdominal fat as well as net return and economic efficiency. 
$\operatorname{Gad}^{1}$ H. A.,et al.

Table (1): Composition and the nutritive value of the basal diets.

\begin{tabular}{|l|c|c|}
\hline Ingredients (\%) & Starter & Grower \\
\hline Yellow corn & 65.00 & 63.00 \\
Soybean meal (44\%) & 30.45 & 15.50 \\
Wheat bran & 0.65 & 17.78 \\
Limestone & 1.40 & 1.80 \\
Dicalcum phosphate & 1.80 & 1.25 \\
Vit. + Min. premix ${ }^{1}$ & 0.30 & 0.30 \\
Salt (NaCl) & 0.30 & 0.30 \\
D.L. Methionine & 0.10 & 0.07 \\
Total & 100.00 & 100.00 \\
Calculated analysis ${ }^{2}:$ & & \\
M.E. (Kcal/kg) & 2864 & 2686 \\
Crude protein (\%) & 19.13 & 15.04 \\
Crude fiber (\%) & 3.72 & 4.48 \\
Ether extracted (\%) & 2.73 & 2.56 \\
Total calcium (\%) & 1.03 & 1.04 \\
Total phosphorus(\%) & 0.72 & 0.72 \\
Methionine (\%) & 0.15 & 0.11 \\
Lysine (\%) & 0.11 & 0.09 \\
Price (LE /Kg diet) $)^{3}$ & 6.10 & 5.40 \\
\hline
\end{tabular}

${ }^{1}$ Contents per 3 kg permix: Vit. A 10000000 IU, Vit. D 1000000 IU, Vit. E 10g, Vit. K 1 g, Vit. $B_{1} 1 \mathrm{~g}$, Vit. $B_{2} 4 \mathrm{~g}$, Nicotinic acid $20 \mathrm{~g}$, Vit. $\mathrm{B}_{6} 1.5 \mathrm{~g}$, Pantothinic acid $10 \mathrm{~g}$, Vit. $\mathrm{B}_{12} 10 \mathrm{~g}$, Folic acid 1g, Biotin $50 \mathrm{mg}$, Choline $500 \mathrm{~g}$, Zinc $45 \mathrm{~g}$, Copper $3 \mathrm{~g}$, Iodine $0.3 \mathrm{~g}$, Iron 30g, Selenium 0.1g, Manganese 40g, Carrier $\mathrm{CaCO}_{3}$ to $3000 \mathrm{~g}$

2 According to NRC (1994).

${ }^{3}$ According to price of different ingredients available in Egypt at the experimental time. 
Table (2): Effect of supplementing dried chamomile flower to Sudani ducklings diet on live body weight (g) and body weight gain (g) at different ages during rearing period.

\begin{tabular}{|c|c|c|c|c|}
\hline \multirow{2}{*}{ Age } & \multicolumn{3}{|c|}{ Chamomile flower (g/kg diet) } & \multirow{2}{*}{ Sig. } \\
\hline & $\mathbf{0 . 0}$ & 1.0 & 3.0 & \\
\hline \multicolumn{5}{|c|}{ Live body weight (g) } \\
\hline At hatch (0week) & $36.73 \pm 0.31$ & $36.80 \pm 0.15$ & $36.87 \pm 0.12$ & NS \\
\hline 4 weeks & $543.73^{a b} \pm 10.77$ & $607.47^{\mathrm{a}} \pm 33.17$ & $525.53^{\mathrm{b}} \pm 16.72$ & $*$ \\
\hline 8 weeks & $1284.73^{\mathrm{ab}} \pm 30.23$ & $1451.80^{\mathrm{a}} \pm 83.48$ & $1155.53^{b} \pm 70.05$ & * \\
\hline 12 weeks & $1842.49^{\mathrm{ab}} \pm 34.70$ & $2040.76^{\mathrm{a}} \pm 81.75$ & $1755.53^{\mathrm{b}} \pm 92.84$ & $*$ \\
\hline 16 weeks & $2294.24^{\mathrm{b}} \pm 68.45$ & $2572.52^{\mathrm{a}} \pm 31.86$ & $2313.59^{\mathrm{b}} \pm 40.93$ & $* *$ \\
\hline \multicolumn{5}{|c|}{ Body weight gain (g) } \\
\hline 0-4 weeks & $507.00^{\mathrm{ab}} \pm 10.58$ & $570.67^{\mathrm{a}} \pm 33.19$ & $488.67^{\mathrm{b}} \pm 16.82$ & $*$ \\
\hline $4-8$ weeks & $741.00^{\mathrm{ab}} \pm 19.60$ & $844.33^{\mathrm{a}} \pm 50.36$ & $630.00^{\mathrm{b}} \pm 55.0$ & $*$ \\
\hline 8-12 weeks & $557.76 \pm 10.84$ & $588.96 \pm 9.89$ & $600.00 \pm 22.81$ & NS \\
\hline $12-16$ weeks & $451.75 \pm 34.20$ & $531.76 \pm 58.41$ & $558.05 \pm 57.01$ & NS \\
\hline $0-16$ weeks & $2257.51^{\mathrm{b}} \pm 68.26$ & $2535.72^{\mathrm{a}} \pm 31.98$ & $2276.72^{\mathrm{b}} \pm 41.03$ & $*$ \\
\hline \multicolumn{5}{|c|}{ Viability $(\%)$} \\
\hline $0-16$ weeks & $92.00 \pm 2.35$ & $90.67 \pm 3.08$ & $93.33 \pm 2.54$ & $\mathrm{NS}$ \\
\hline
\end{tabular}

$\mathrm{a}$ and $\mathrm{b}$ Means with different superscripts within rows are significantly different $(\mathrm{P} \leq 0.05)$.

$\mathrm{NS}=$ not significant $\quad *=$ significant at $\mathrm{P} \leq 0.05 \quad * *=$ significant at $\mathrm{P} \leq 0.01$. 
Table (3): Effect of supplementing dried chamomile flower to Sudani ducklings diet on feed consumption (g. feed/duckling/period), feed conversion ratio(g. feed/g. body gain /bird/period) and performance index (\%) at different ages during rearing period.

\begin{tabular}{|c|c|c|c|c|}
\hline \multirow{2}{*}{ Age } & \multicolumn{3}{|c|}{ Chamomile flower (g/kg diet) } & \multirow{2}{*}{ Sig. } \\
\hline & $\mathbf{0 . 0}$ & 1.0 & 3.0 & \\
\hline \multicolumn{5}{|c|}{ Feed consumption (g. feed/duckling/period) } \\
\hline 0-4 weeks & $1973.33 \pm 28.03$ & $2075.00 \pm 42.57$ & $1963.33 \pm 55.78$ & NS \\
\hline 4-8 weeks & $3276.67 \pm 43.40$ & $3243.33 \pm 37.78$ & $3168.67 \pm 43.36$ & NS \\
\hline 8-12 weeks & $3627.67 \pm 39.01$ & $3648.67 \pm 51.59$ & $3635.00 \pm 31.94$ & NS \\
\hline 12-16 weeks & $3795.33 \pm 30.17$ & $3768.33 \pm 24.82$ & $3721.67 \pm 17.57$ & NS \\
\hline $0-16$ weeks & $12673.00 \pm 75.04$ & $12735.33 \pm 77.81$ & $12488.67 \pm 139.49$ & NS \\
\hline \multicolumn{5}{|c|}{ Feed conversion ratio (g. feed/g. body gain) } \\
\hline $0-4$ weeks & $3.90 \pm 0.10$ & $3.66 \pm 0.24$ & $4.02 \pm 0.04$ & $\mathrm{NS}$ \\
\hline 4-8 weeks & $4.43^{\mathrm{ab}} \pm 0.18$ & $3.87^{\mathrm{b}} \pm 0.24$ & $5.10^{\mathrm{a}} \pm 0.41$ & $*$ \\
\hline 8-12 weeks & $6.51 \pm 0.12$ & $6.20 \pm 0.17$ & $6.07 \pm 0.17$ & NS \\
\hline 12-16 weeks & $8.50 \pm 0.62$ & $7.27 \pm 0.83$ & $6.82 \pm 0.75$ & NS \\
\hline 0-16 weeks & $5.62 \pm 0.19$ & $5.02 \pm 0.05$ & $5.49 \pm 0.05$ & NS \\
\hline \multicolumn{5}{|c|}{ Performance index (\%) } \\
\hline $0-4$ weeks & $13.99 \pm 0.57$ & $16.86 \pm 2.09$ & $13.08 \pm 0.51$ & NS \\
\hline 4-8 weeks & $29.13^{a b} \pm 1.79$ & $38.10^{\mathrm{a}} \pm 4.68$ & $23.22^{\mathrm{b}} \pm 3.44$ & $*$ \\
\hline 8-12 weeks & $28.35 \pm 1.03$ & $32.93 \pm 1.14$ & $29.05 \pm 2.40$ & NS \\
\hline 12-16 weeks & $27.39 \pm 2.65$ & $36.20 \pm 3.57$ & $34.57 \pm 3.03$ & NS \\
\hline $0-16$ weeks & $40.96^{b} \pm 2.55$ & $51.23^{\mathrm{a}} \pm 1.08$ & $42.18^{\mathrm{b}} \pm 1.09$ & $*$ \\
\hline
\end{tabular}

a and b Means with different superscripts within rows are significantly different $(\mathrm{P} \leq 0.05)$.

$\mathrm{NS}=$ not significant $\quad *=$ significant at $\mathrm{P} \leq 0.05$. 
Table (4): Effect of supplementing dried chamomile flower to Sudani duckling's diet on carcass traits at 16 weeks of age

\begin{tabular}{|c|c|c|c|c|}
\hline \multirow{2}{*}{ Traits } & \multicolumn{3}{|c|}{ Chamomile flower (g/kg diet) } & \multirow{2}{*}{ Sig. } \\
\hline & 0.0 & 1.0 & 3.0 & \\
\hline Live body weight, $\mathrm{g}$ & $2297.83 \pm 14.41$ & $2571.24 \pm 13.91$ & $2318.65 \pm 18.73$ & NS \\
\hline Total edible parts, $\%$ & $69.67 \pm 0.39$ & $70.35 \pm 0.54$ & $70.39 \pm 0.55$ & NS \\
\hline Eviscerated. Carcass, $\%$ & $65.87 \pm 0.37$ & $65.77 \pm 0.55$ & $66.10 \pm 0.60$ & NS \\
\hline Total giblets, $\%$ & $3.80^{\mathrm{b}} \pm 0.14$ & $4.59^{\mathrm{a}} \pm 0.23$ & $4.29^{\mathrm{ab}} \pm 0.22$ & $*$ \\
\hline Liver, \% & $1.44 \pm 0.07$ & $1.82 \pm 0.21$ & $1.66 \pm 0.14$ & NS \\
\hline Gizzard, \% & $1.53^{\mathrm{b}} \pm 0.10$ & $1.93^{\mathrm{a}} \pm 0.09$ & $1.68^{\mathrm{ab}} \pm 0.14$ & $*$ \\
\hline Heart, \% & $0.83^{b} \pm 0.03$ & $0.84^{\mathrm{b}} \pm 0.03$ & $0.95^{\mathrm{a}} \pm 0.03$ & * \\
\hline Abd. fat $(\mathrm{mg} / 100 \mathrm{~g})$ & $1634.00^{\mathrm{a}} \pm 77.57$ & $676.00^{\mathrm{b}} \pm 65.01$ & $510.00^{\mathrm{b}} \pm 34.64$ & $* *$ \\
\hline
\end{tabular}

$\mathrm{a}$ and $\mathrm{b}$ Means with different superscripts within rows are significantly different $(\mathrm{P} \leq 0.05)$.

$\mathrm{NS}=$ not significant $*=$ significant at $\mathrm{P} \leq 0.05 \quad * *=$ significant at $\mathrm{P} \leq 0.01$. 
Table (5): Effect of supplementing dried chamomile flower to Sudani duckling's diet on plasma lipid profile, liver function and blood hematological parameters at 16 weeks of age

\begin{tabular}{|c|c|c|c|c|}
\hline \multirow{2}{*}{ Parameters } & \multicolumn{3}{|c|}{ Chamomile flower (g/kg diet) } & \multirow{2}{*}{ Sig. } \\
\hline & 0.0 & 1.0 & 3.0 & \\
\hline \multicolumn{5}{|c|}{ Lipid profile } \\
\hline T. lipid(mg/dl) & $2057.8^{\mathrm{a}} \pm 118.13$ & $1639.1^{\mathrm{b}} \pm 94.35$ & $1607.73^{b} \pm 92.25$ & $*$ \\
\hline Triglycerides $(\mathrm{mg} / \mathrm{dl})$ & $171.97^{\mathrm{a}} \pm 4.19$ & $121.17^{\mathrm{b}} \pm 2.23$ & $109.71^{\mathrm{c}} \pm 2.86$ & $*$ \\
\hline T. Cholst. $(\mathrm{mg} / \mathrm{dl})$ & $149.36^{\mathrm{a}} \pm 3.53$ & $123.33^{\mathrm{b}} \pm 5.72$ & $105.18^{c} \pm 7.35$ & $* *$ \\
\hline $\mathrm{HDL}(\mathrm{mg} / \mathrm{dl})$ & $127.05^{\mathrm{a}} \pm 5.25$ & $106.00^{\mathrm{b}} \pm 5.34$ & $92.50^{\mathrm{b}} \pm 6.75$ & $*$ \\
\hline $\mathrm{LDL}(\mathrm{mg} / \mathrm{dl})$ & $17.29^{\mathrm{a}} \pm 1.25$ & $13.29^{\mathrm{b}} \pm 1.16$ & $10.24^{\mathrm{b}} \pm 0.68$ & $* *$ \\
\hline $\operatorname{VLDL}(\mathrm{mg} / \mathrm{dl})$ & $5.02^{\mathrm{a}} \pm 0.91$ & $4.04^{\mathrm{ab}} \pm 0.22$ & $2.44^{\mathrm{b}} \pm 0.16$ & $* *$ \\
\hline \multicolumn{5}{|c|}{ Liver function } \\
\hline T. Protein $(\mathrm{g} / \mathrm{dl})$ & $7.03 \pm 0.44$ & $7.00 \pm 0.06$ & $7.90 \pm 0.21$ & NS \\
\hline Albumin (g/dl) & $1.87^{b} \pm 0.67$ & $5.00^{\mathrm{a}} \pm 0.03$ & $4.97^{\mathrm{a}} \pm 0.26$ & $* *$ \\
\hline Globulin (g/dl) & $5.17^{\mathrm{a}} \pm 0.23$ & $2.00^{\mathrm{b}} \pm 0.06$ & $2.93^{\mathrm{b}} \pm 0.38$ & $* *$ \\
\hline $\mathrm{A} / \mathrm{G}$ ratio $(\%)$ & $0.37^{\mathrm{c}} \pm 0.15$ & $2.50^{\mathrm{a}} \pm 0.07$ & $1.77^{\mathrm{b}} \pm 0.27$ & $* *$ \\
\hline ALT (I.U./L) & $38.67^{\mathrm{b}} \pm 1.33$ & $43.33^{\mathrm{b}} \pm 4.41$ & $56.67^{\mathrm{a}} \pm 4.41$ & $*$ \\
\hline AST (I.U./L) & $44.00^{\mathrm{b}} \pm 2.08$ & $50.00^{\mathrm{b}} \pm 2.89$ & $63.67^{\mathrm{a}} \pm 11.26$ & $*$ \\
\hline \multicolumn{5}{|c|}{ Hematological parameters } \\
\hline $\mathrm{HB}(\mathrm{g} / \mathrm{dl})$ & $9.50 \pm 1.04$ & $10.67 \pm 0.33$ & $10.67 \pm 0.33$ & NS \\
\hline $\mathrm{RBC}$ & $3.00 \pm 0.12$ & $3.07 \pm 0.03$ & $3.07 \pm 0.07$ & NS \\
\hline WBC (x103/mm3) & $11.00^{\mathrm{b}} \pm 5.77$ & $15.00^{\mathrm{a}} \pm 5.77$ & $16.00^{\mathrm{a}} \pm 5.77$ & $* *$ \\
\hline
\end{tabular}

$\mathrm{a}, \mathrm{b}$ and $\mathrm{c}$ Means with different superscripts within rows are significantly different $(\mathrm{P} \leq 0.05)$.

$\mathrm{NS}=$ not significant $\quad *=$ significant at $\mathrm{p} \leq 0.05 \quad * *=$ significant at $\mathrm{p} \leq 0.01$. 
Table (6): Effect of supplementing chamomile flower to Sudani ducklings diet during rearing period on economic efficiency.

\begin{tabular}{|c|c|c|c|}
\hline \multirow{2}{*}{ Parameters } & \multicolumn{3}{|c|}{ Chamomile flower (g/kg diet) } \\
\hline & 0.0 & 1.0 & 3.0 \\
\hline Feed consumption, $(\mathrm{Kg})$ & 12.67 & 12.74 & 12.49 \\
\hline Feed cost, $(\mathrm{LE})^{1}$ & 69.82 & 71.50 & 70.06 \\
\hline Additive cost, $(\mathrm{LE})^{2}$ & 0.00 & 0.76 & 2.25 \\
\hline Total feed cost, $(\mathrm{LE})^{3}$ & 69.82 & 72.26 & 72.31 \\
\hline Total production $\operatorname{cost}(\mathrm{LE})^{4}$ & 99.74 & 103.22 & 103.30 \\
\hline Body weight gain, $(\mathrm{Kg})$ & 2.26 & 2.54 & 2.28 \\
\hline Viability at market $(\%)$ & 92.00 & 90.67 & 93.33 \\
\hline Total revenue, $(\mathrm{L} . \mathrm{E})^{5}$ & 103.96 & 115.15 & 106.40 \\
\hline Net revenue, (L.E) ${ }^{6}$ & 4.22 & 11.93 & 3.09 \\
\hline Economic efficiency $(\%)^{7}$ & 4.23 & 11.55 & 2.99 \\
\hline
\end{tabular}

${ }^{1}$ L.E. = Egyptian pound.

${ }^{2}$ The price of chamomile flower $(60 \mathrm{LE} / \mathrm{Kg})$.

${ }^{3}$ Total feed cost $=$ feed cost + additive cost.

${ }^{4}$ Assuming that the feed cost as $70 \%$ of the total production cost according to (Singh et al; 2015).

${ }^{5}$ Total revenue $=$ body weight gain $(\mathrm{Kg}) \times$ Viability at market $(\%) \times$ price of one $\mathrm{kg}$ at selling which was $50 \mathrm{~L} . \mathrm{E}$.

${ }^{6}$ Net revenue $=$ Total revenue - Total production cost

${ }^{7}$ Economic efficiency $(\%)=$ Net revenue $($ L.E) $/$ Total production cost $($ L.E) $\times 100$. 


\section{REFERENCES}

Abaza I. M., Asar M. A., El-Shaarrawi G. E. and Hassan M. F. 2003. Effect of using Nigella seed, Chamomile flower, Thyme flower and Harmala seed as feed additives on performance of broiler. Egypt. J. Agric. Res., 81: 735-749.

Abd El-Latif S. A., El-Yamany A.T. and Eman A. F. Edaly 2003. Evaluation of using different levels and sources of medical herbs in growing Japanese quail diets. Egypt. J. Nutr. and Feeds, 6: 219-220.

Awad A. L., Hussein M. A., Ghonim A. I., Kasim, M.G. and Humoda I. A. 2009. Effect of using rice bran in Domyati ducklings diets on growth performance and carcass quality. Egypt Poult. Sci., 29 : 173 - 189.

Babenko N. O. and Shakhova O. H. 2005. Age-dependent effects of flavonoids on secretory function of the rat liver. Fiziol Zh, 51 : 65-69.

Capasso R., Savino F. and Capasso F. 2007. Effects of the herbal formulation ColiMil on upper gastrointestinal transit in mice in vivo. Phytother Res., 10, 21 : 999-1101.

Dada R M. T. and Tabeidian S. A. 2015. The Effect of chamomile flower (Matricaria chamomilla L.) extract and powder as growth promoter on growth performance and digestive organs of broiler chickens. Res. Opin. Anim. Vet. Sci., 5 : 290-294.

Duncan, D.B. 1955. Multiple range and multiple F tests. Biometrics, 11: 1-45.

El-Soukkary F.A., Mohamed H. M., Dawood, A. A. and Abd-El Sayed S.Y. 2005. Physico-chemical, microbiological and lipid characteristics of duck meat. Minufiya J. Agric. Res., 30: 527-548.
Feed Composition Tables for Animals and Poultry Feedstuffs Used in Egypt. 2001. Technical Bulletin No., 1, Central Lab. For Food and Feeds (CLFF) Ministry of Agric. Res. Cent. Egypt.

Galib A. M. A. and Khalel E. K.2011. The potency of chamomile flowers (Matericaria chamomilla L.) feed supplements (growth promoters) on productive performance and hematological parameters constituents of broilers. Int. J. Poult. Sci., 10 : 726729.

Gosztola A. B., Nemeth E., Kozak A., Sarosi S. Z. and Szabo K. 2006. Comparative evaluation of Hungarian chamomile (Matricaria recutita. L) populations. $1^{\text {st }}$ Int. Symp. on chamomile Research, Develop. and Prod., pp: 34.

Haddad, E. E. 1989. Immuno-endocrine interaction. $\mathrm{Ph}$. D. Thesis, The Pennsylvania State Univ.

Heady E. O. and Jensen H. R. 1954. Farm Management Economics PrenticHall, Inc. Englewood Clidds, N.J.

Ibrahim D. Kh. And Butris G. Y. 2008. Effect of supplementing chamomile flowers as powder to diet or boiling aqueous extract to drinking water on some productive characters of broiler during heat stress. Egypt. J. Nut. and Feeds, 11: 431-445.

Ibrahim Sh. A., El Ghamry A. A., El. Allawy H. M., Ali F.A. and Nagwa Magrabi 2014. The effect of chamomile flower as feed additive on fat deposition in certain subcutaneous tissues, carcass quality and growth performance in Pekin duck. Global Vet.13: 767-773.

Jain N.C.1986. Schalm Veteniary Haemotology. $4^{\text {th }}$ edition Philadelphia, Lea and Ferbinger. 
Chamomile flower-growth performance-abdominal fat-cholesterol and ducklings.

Kout Elkloub M. El-Moustafa., Awad

A. L. and Ghonim A.I.2010. Response of Domyati ducklings to diets containing different levels of metabolizable energy and crude protein: 1- During growth period. Egypt Poult. Sci., 30: 535 -564.

Leung A.Y., and Foster S.1996. Encyclopedia of common natural ingredients used in food, drugs and cosmetics, $2^{\text {nd }}$ ed. New york: John Wiley and Sons, Inc.

Mahmmod Z. A.2013. The effect of chamomile plant (Matericaria chamomile L.) as feed additives on productive performance, carcass characteristics and immunity response of broiler. Int. J. Poult. Sci., 12 : 111116.

McCrea B. K., Macklin J. H., Norton R. and Bilgili, S.2005. Recovery of campylobacter Jujunum from broiler house samples during four consecutive flocks, Dendrogram, Auburn Uni.Auburn, Alabama, USA.

McKay, D.L. and J.B .Blumberg 2009. A review of the bioactivity and potential health benefits of chamomile tea (Matricaria recutita L.). Human Nut. Res. Center on Aging at Tufts Uni. USA., 20 :519- 530.

Merlin N. J. and Parthasarathy V. 2011. Antioxidant and hepatoprotective activity of chloroform and ethanol extracts of gmelina asiatica aerial parts, J. Med. Plants Res., 5 :533-538.

Muhamad A., Tamzil, M. H. and Ichsan M. 2014. Meat traits of Muscovy ducks fed on phytonutrition meal. Int. J. Poult. Sci., 13: 204-207.

Namur A. P., J Morel and Bichek H. 1988. Compound animal feed and feed additives. In Deboer, F., H. BICHEl, eds. Livestock feed resources and feed evaluation in Europe. Elsevier. Sci. publ., Amsterdam.

North M.O.1984. Commercial chickens production manual. $3^{\text {rd }}$ edition. AVI Publishing Company Inc. West port, Connecticut. U.S.A.

Panda H. 2005. Handbook on medicinal herbs with uses. Asia Pacific Business Press Inc. 106-E, Kamla Nagar, Delhi110007 , India.

Radwan Nadia L. 2003. Effect of using some medicinal plants on performance and immunity of broiler chicks. Ph. D. Thesis, Fac. of Agric. Cairo Univ., Egypt.

Ramadan K. S. and Emam M. A. 2012. Biochemical evaluation of antihyperglycemic and antioxidative effects of matriceria chamomilla leave extract studied in streptozotocininduced diabetic rats, Int. J. Res. Manag. and Tech., 2: 2249-2263.

Saberi H., Jabri M. A., Souli A., ElBenna J., Sakly M. 2014. Antidiarrheal and antioxidant activities of chamomile (Matricaria recutita L.) decoction extract in rats. J Ethnopharm, $152:$ 327-332.

SAS 2001. SAS User's guide: Statistics, Version $9^{\text {th }}$ Ed. SAS Institute Inc., Cary N.C., USA.

Singh M.K., Singh S.K., Sharma R.K., Singh B., Kumar S.2015. Performance and carcass characteristics of guinea fowl fed on dietary Neem (Azadirachta indica) leaf powder as a growth promoter. Iran. J. Vet. Res., 16: 78-82.

Soltan M. E., Enab A. A., Gebriel G. M. and Kandil M. S. 2014. Meat production efficiency of two lines of Pekin ducks under two different feeding systems. Minufiya J. Agric. Res., 39:521-535.

Tietz N. W.1990. Clinical guide to laboratory tests. $2^{\text {th }}$ Ed. Philadelphia. WB, Saunders. 566. 
$\operatorname{Gad}^{1}$ H. A.et al.

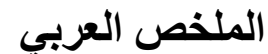

$$
\begin{aligned}
& \text { تأثير إضافة زهرة البابونج للعليقة على الأداء الانتاجى للبط السودئ البودانى أثناء فترة نمو }
\end{aligned}
$$

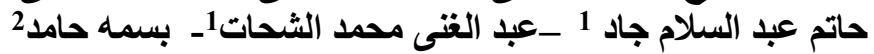

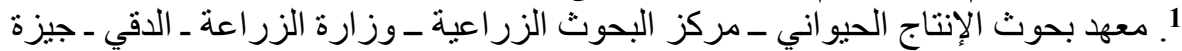

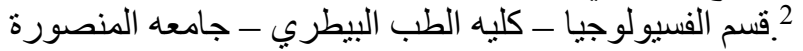

إستخدم في هذه الدر اسة عدد 225 كتكوت بط سودانى عمر يوم وذللك لدر اسة تأثير إضافة مستويات مختلفة من

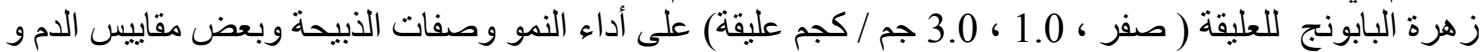

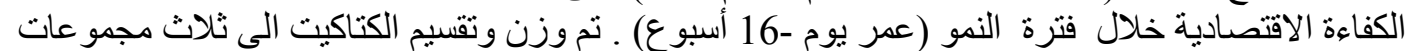

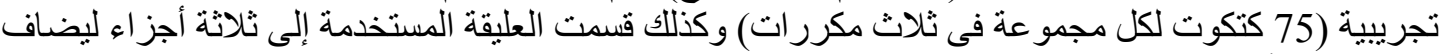

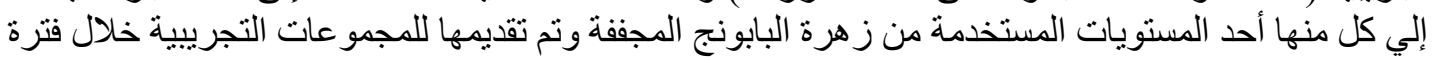
التجربة.

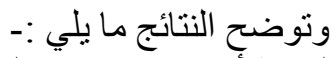

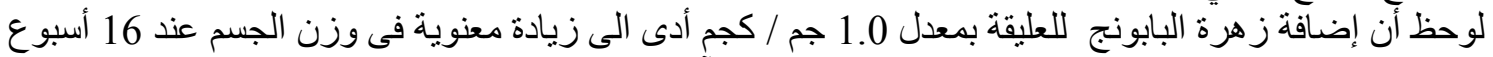

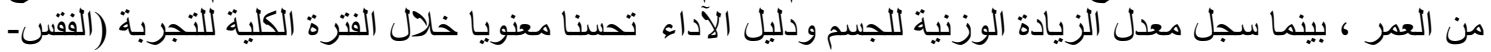

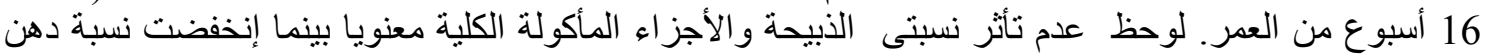

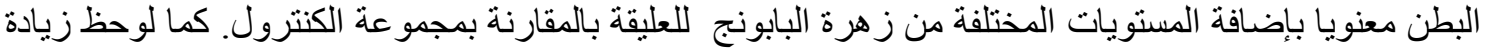

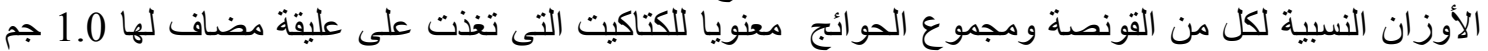

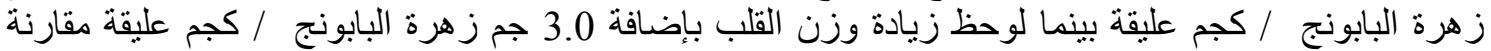

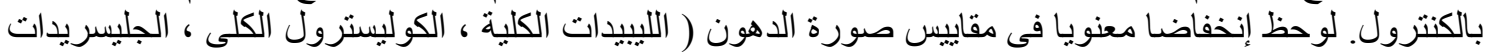

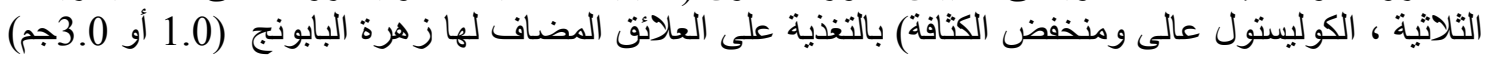

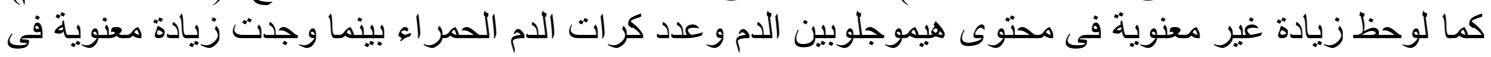

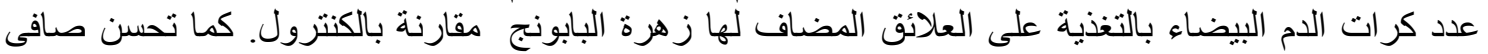

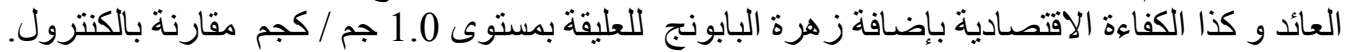

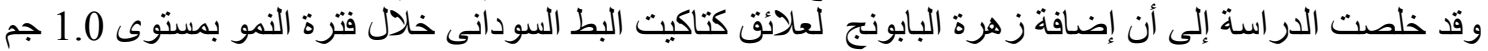

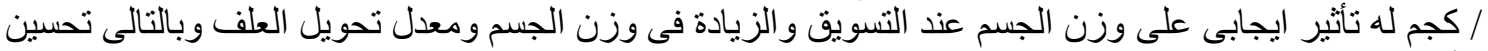
الأداء الانتاجى وصفات الذبيحة فضلا عن تحسن صافى العائد و الكفاءة الاقتصادية. 